\title{
The marketing orientation as a university management philosophy: a framework to guide its application
}

\author{
El enfoque de marketing como filosofía de gestión \\ de las universidades: un marco de trabajo para \\ orientar su aplicación
}

\author{
Amaia Lafuente-Ruiz-De-Sabando ${ }^{1}$ \\ JAVIER FORCADA \\ Pilar Zorrilla ${ }^{2}$ \\ Universidad del País Vasco UPV/EHU (España)
}

Recibido el 4 de septiembre de 2015, aceptado el 6 de junio de 2016

Publicado online el 25 de enero de 2017

$\mathrm{N}^{\mathrm{o}}$ de clasificación JEL: I23, M31

DOI: $10.5295 / \mathrm{cdg} .150576 \mathrm{al}$

\begin{abstract}
:
The environment in which university institutions develop their activities has become more competitive over recent decades and market elements have been introduced into the sector. Accordingly, universities have shown a growing interest in developing and maintaining a favourable and distinctive image among their stakeholders. To this end, many of them have focused their efforts on the improvement and renewal of training programs. However, such efforts have not always been matched in the transmission of a more favourable perception among their stakeholders. This context calls for university management with a marketing orientation. However, university marketing is in its early stages in many parts of the world and the incorporation of marketing principles and practices in the field of higher education encounters much reluctance from citizens and academics. This contribution sets out the reasons for this resistance, which may be grounded in a misconception about the discipline, and a working framework for marketing management in universities is proposed to facilitate the practical implementation of marketing philosophy in such institutions. It is a framework whose design involves a combination of services marketing and corporate marketing proposals and highlights aspects that managers of higher education institutions should focus on 1) to meet the demands of different stakeholders with varied (and sometimes conflicting) interests and 2) to move towards the development of a favourable perception among the stakeholders of the institutions they manage.
\end{abstract}

Keywords:

University, higher education, image, marketing orientation, market orientation, marketing management.

\footnotetext{
1 Department of Financial Economics II, Faculty of Economics and Business, Comandante Izarduy 23, 01006 Vitoria-Gasteiz (Spain). amaia.lafuente@ehu.eus; javier.forcada@ehu.eus

${ }^{2}$ Department of Financial Economics II, Faculty of Economics and Business, Lehendakari Aguirre 83, 48015 Bilbao (Spain).pilar.zorrilla@ehu.eus
} 


\section{Resumen:}

El entorno universitario se ha vuelto más competitivo durante las últimas décadas y se han introducido en el sector elementos de mercado. Por esta razón, las universidades han identificado la necesidad de contar con una imagen favorable y distintiva entre sus grupos de interés. Para lograrlo, muchas han concentrado sus esfuerzos en la mejora de los programas formativos, aunque ello no se ha visto siempre correspondido en términos de una percepción más favorable entre los stakeholders. Este contexto demanda una gestión de las universidades bajo un enfoque de marketing. Sin embargo, el marketing universitario se encuentra en una fase incipiente en muchas partes del mundo y la incorporación de los principios y prácticas del marketing al ámbito de la Educación Superior cuenta con numerosas reticencias entre ciudadanos y académicos. En este artículo se exponen las razones que han podido motivar tales reticencias, cuyo origen puede estar en un mal entendimiento de la disciplina, y se propone un marco de trabajo para la gestión del marketing en las universidades orientado a facilitar la puesta en práctica de la filosofía de marketing en este tipo de organizaciones. Se trata de un esquema diseñado a partir de la integración de propuestas procedentes del marketing de servicios y del marketing corporativo en el que se destacan los aspectos sobre los que poner el foco para 1) dar respuesta a las demandas de un conjunto de colectivos con intereses variados (e, incluso, contrapuestos) y 2) avanzar hacia el desarrollo de una percepción favorable entre los stakeholders.

\section{Palabras clave:}

Universidad, Educación Superior, imagen, orientación al marketing, orientación al mercado, gestión del marketing. 


\section{INTRODUCTION}

Universities in different parts of the world have witnessed important transformations of the environment in which their activities unfolded (Soutar and Turner 2002; Maringe 2005; Bugandwa 2009; Rivera-Camino and Molero Ayala 2010; Filip 2012; Tanrikulu and Gelibolu 2015; Tran et al. 2015; Llonch et al. 2016) and have observed that different phenomena intensified the degree of competition in the sector and brought in market elements (García Sanchis 2012; Tanrikulu and Gelibolu 2015; Tran et al. 2015). Aware of the greater intensity of competition, universities have shown more interest in developing and maintaining a favourable distinctive image or reputation (Curtis et al. 2009; Maringe and Mourad 2012), since "[it] has been identified as one of the main factors affecting higher education (HE) choice (Hemsley-Brown and Oplatka 2016, p.113)". To this end, many have responded by concentrating their efforts on renewing their training programmes and trying to improve quality (Bugandwa 2009). But, paradoxically, the efforts made have not always been matched in terms of transmission of a more favourable perception to the student body or other stakeholders of university institutions. Indeed, in different parts of the world citizens have been critical of their universities, calling for better adaptation to student expectations, to the needs of the business fabric and to social demands (Hemsley-Brown and Oplatka 2010; Filip 2012).

In this regard, although reality and perception do not always coincide and the criticisms might be due to image distortion, we believe that the situation described might hide a more serious problem: superficial knowledge of what the different stakeholders expect of the university, of what their needs are and how they should best be satisfied. The fact is that it has been taken for granted that the main need of students who attend their lecture rooms is training although, in reality, little research has gone into finding out the importance of other motivations such as improvements in professional expectations, aspirations of achieving a certain status, living out experiences or developing social relations. Then again, students are not the only collective the universities have a debt to. Indeed, there are different stakeholders with interests and motivations that do not always coincide with those of the students and, on occasion, may even turn out to be conflicting. But there is still little known about them.

This is why we feel that the moment has come for universities to consider deeper changes than improvements in training programmes and the reform of degree courses. It is time to rethink what is the most suitable management approach to meet the needs of their various stakeholders and to build a favourable image. Specifically, it is our consideration that the incorporation of marketing principles and practices within university management would enable an improvement in their image and an evolution better tuned to the social needs and expectations of their different interest groups. The main reason is that this management philosophy is rooted in value creation for stakeholders, which obliges organizations to identify what is important for each collective, and the alternatives that exist to provide it for them. Therefore, in addition to improving training programmes, which should form part of the universities' value proposition, our understanding is that a deeper knowledge of the stakeholders would pave the way for the incorporation of elements directed at generating more satisfactory service experiences. 
Although concern that there should be a marketing orientation appeared several decades ago in some countries (as in the North American university system), university marketing has as yet scarcely been applied in certain parts of the world (Bugandwa 2009; Maringe and Gibbs 2009; Maringe and Mourad 2012; Alarcón-del-Amo et al. 2016) and great reluctance can be detected among citizens and academics (Maringe and Mourad 2012; Winter and O'Donohue 2012; Alnawas 2015) at the idea of principles originating in the business sphere being transferred into the sector. We coincide with other authors (Maringe 2004; Maringe 2005; Maringe and Mourad 2012) in the view that the origin of the resistance is to be found in a poor understanding of marketing discipline. This resistance and lack of familiarity is even observed among university managers themselves (Newman 2002; Maringe 2005; Hayes 2007; Filip 2012), which proves to be particularly problematic given that it is they who ought to spearhead the change, spreading marketing philosophy among the rest of the staff of the universities they direct (Tran et al. 2015). Consequently, having once set out the reasons that lead us to the opinion that marketing philosophy, correctly applied, is eminently suitable for balancing the interests of universities, stakeholders and society, we propose a framework designed to facilitate its implementation in universities. This is precisely the objective of this work. We hope, thereby, to provide university managers with a tool that can assist them to incorporate marketing principles and practices within management, because we believe that would help universities to successfully face up to the present context, provide a response to the demands of their different stakeholders and move towards the construction of a favourable image.

\section{THE HOLISTIC MARKETING ORIENTATION AS A UNIVERSITY MANAGE- MENT PHILOSOPHY}

In the business field, the marketing orientation as a central element of management philosophy grounded in the marketing concept, has been presented as a fundamental resource for the creation of lasting and sustainable competitive advantages. For the field we are dealing with, that of HE, in the early 1980s Keller (1983) predicted a growing importance of the marketing application in the sector and, since then, several authors have agreed on the desirability of adopting a marketing perspective (for instance, Çetin 2004; Flavián and Lozano 2004; Ma and Todorovic 2011; Filip 2012; Stimac and Simic 2012; Kalenskaya et al. 2013; Tanrikulu and Gelibolu 2015; Tran et al. 2015). Further, a gradual increase is observed in the number of universities that incorporate marketing principles and practices within management (Kotler and Fox 1995; Yavas and Shemwell 1996; Newman 2002; Soutar and Turner 2002; Hemsley-Brown and Oplatka 2006; Hayes 2007; Liao 2008; Curtis et al. 2009; Wasmer and Bruner II 2009; Hemsley-Brown and Oplatka 2010; Cardoso et al. 2011; Filip 2012; García Sanchis 2012; Kalenskaya et al. 2013; Tran et al. 2015) and that show more concern about becoming market oriented (Mavondo et al. 2008; Ressler and Abratt 2009; Cardoso et al. 2011; Gattermann et al. 2012; Kalenskaya et al. 2013; Tran et al. 2015), especially among private institutions (Bardo et al. 1990; Maringe and Gibbs 2009; Cardoso et al. 2011).

Nonetheless, university marketing is still in its very early stages in many parts of the world (Bugandwa 2009; Maringe and Gibbs 2009; Maringe and Mourad 2012; Alarcón- 
del-Amo et al. 2016) and "has been approached mainly from the operational level as tools for student recruitment and income generation (Liu 1998, p.17)". Among the most powerful causes of this delay in the application of marketing principles and practices in the HE field is the scant training and insufficient expertise that many university managers possess in this area (Newman 2002; Maringe 2005; Hayes 2007; Filip 2012). Perhaps that is why, in many institutions, marketing is still "under suspicion" for being a concept imported from the business world (Naude and Ivy 1999; Maringe 2005; Hayes 2007) and, as pointed out by Nedbalová et al. (2014), different authors "consider marketing to be an evil practice which damages education by using business techniques (p.178)". Consequently it encounters much resistance both from citizens and academics (Maringe and Mourad 2012; Winter and O'Donohue 2012; Alnawas 2015), who mistake it for a mere tool for recruiting students, generating income and raising funds (Conway et al. 1994; Mainardes et al. 2014), and disapprove of principles that have arisen in the business field being brought into the sector (Curtis et al. 2009; Natale and Doran 2012; Winter and O'Donohue 2012) along with concepts that until recently were foreign to them, such as "competition", "competitive advantage", "customers", "client satisfaction" or "market" (Bugandwa 2009; Alnawas 2015). This reticence, however, is the result of a misunderstanding of the discipline (Maringe 2004; Maringe 2005; Hayes 2007; Maringe and Mourad 2012), whereby it is perceived as being centred on the generation of profits and is frequently taken to be synonymous with advertising and sales (Liu 1998; Hayes 2007; Hemsley-Brown and Oplatka 2010).

But this popular belief is far removed from current marketing philosophy and may have been fostered 1) by its earliest definitions and conceptualizations, and 2) by orientations characteristic of the first stages of development of marketing in organizations. In its original conceptualization, marketing was considered to be a purely entrepreneurial activity whose aim was to place on the market products manufactured by companies. However, in the most recent definition proposed by the American Marketing Association (AMA), marketing was defined as "the activity, set of institutions, and processes for creating, communicating, delivering, and exchanging offerings that have value for customers, clients, partners, and society at large (AMA 2013)". This makes explicit that marketing heads must not only be concerned about the needs of customers, but also of those of other stakeholders and of society as a whole. It is therefore true that the first definitions proposed for the marketing concept did not fit in with the characteristics universities possess as organizations, with the services they provide, with the stakeholders they address and with the aims they pursue. However, the evolution the discipline has experienced has given rise to broader conceptualizations that are adaptable to the particularities of higher education institutions (HEIs).

With regard to the evolution of marketing management in organizations, academics have also identified different stages of development. These stages have frequently been referred to as production orientation, product orientation, sales orientation and marketing orientation, and they differ from each other in the focus through which organizations conceive relations of exchange with their stakeholders and confront the challenges of the environment. Over recent years, some extensions have also been developed for the classical marketing orientation, amongst which we would highlight the societal marketing orientation and holistic marketing orientation due to their potential for adapting particularly well to the functions of universities. The differences between the different focuses mentioned are 
determined by the historical conditions of markets (strongly associated with the existing degree of competition) and they lie, basically, in the relative importance that is attributed to satisfaction of the interests of the organization, of the customers, of society in general and of other stakeholders.

In the HE field, during the second half of the $20^{\text {th }}$ century several university systems became immersed in a phenomenon of unprecedented growth in demand. This situation caused existing universities to concentrate on favouring the growth of student places available in their facilities and stimulated the emergence of new universities that did not need to make any effort to fill up their classrooms. In that context, a production orientation extended throughout universities. The later stagnation and even reduction in demand as a consequence of the population decrease in the university age group, gave rise to a stage characterized by the unfolding of initiatives (grounded in the development of communication actions) geared to student recruitment (sales orientation) or focused on permanent efforts to improve the programmes to be delivered to university students (product orientation). In fact, product orientation is what predominates in university institutions (Maringe 2005; Kalenskaya et al. 2013; Alnawas 2015), "based on the perception of expertise with which universities tend to associate themselves (Maringe 2005, p.571)". Whilst improvements in training programmes ought to be one of the constant challenges for universities as a consequence of their status as providers of the HE service, we consider that these should necessarily be complemented with analysis and reflection concerning the needs of customers (or, as we propose below, of a set of stakeholders) in order to properly meet those needs (marketing orientation). As stated previously, this attempt to understand and satisfy customer needs and problems reflects a "marketing orientation", which several authors have also termed "market orientation" and "customer orientation" (Siu and Wilson 1998).

Nevertheless, the proposal of a management approach which includes customer orientation among its cornerstones keeps open the debate as to who the university customer is, as well as to the consideration that students are customers (Marzo et al. 2007; Rivera-Camino and Molero Ayala 2010; Woodall et al. 2014; Koris and Nokelainen 2015), and has put on its guard a critical sector that fears a possible deterioration in student training if universities perceive students as such (Mägi et al. 2012; Saunders 2014). Both matters reveal that, despite the efforts made by different authors to operationalize the marketing concept in the HE field, more reflection is needed in order to move on and put forward proposals that enhance theory-building, facilitate application of the marketing concept in this area and encourage an understanding of marketing philosophy as an approach suitable for the management of universities where both their managers and their staff are concerned.

\subsection{Market orientation concept in the field of higher education: the need for an im- proved adaptation to context}

The market orientation, understood as the operationalization of the marketing concept, has attracted great attention in business-related marketing literature over recent decades. As time has passed, researches have been extended to different contexts such as the university field. And, although recent works continue to point to the dearth of literature dealing with the market orientation in HE (Bugandwa 2009; Rivera-Camino and Molero Ayala 2010; Ma and Todorovic 2011; Tran et al.2015), a growing trend is observed in the number 
of empirical works published on this question (a tendency that becomes sharper from 2010 onwards), which denotes the existence of a clear interest among researchers in making advances towards adapting and transferring the market orientation concept to the university sector.

As for the direction taken by research on the market orientation concept in the field of $\mathrm{HE}$, some works have focussed on the development of valid and reliable scales to measure how it is applied (Hammond et al. 2006; Voon 2008; Hemsley-Brown and Oplatka 2010; Küster and Avilés-Valenzuela 2010; Rivera-Camino and Molero Ayala 2010; Llonch et al. 2016). The possibilities and problems that HEIs experience in making the transfer from a traditional approach to one of market orientation (Siu and Wilson 1998) or the degree to which universities or the university systems of different countries target the market (Stewart 1991; Hammond et al. 2006; Pavicic et al. 2009; Bakar et al. 2014) have also been studied, even managing to establish comparisons among them (Hemsley-Brown and Oplatka 2010). With regard to the relations between the market orientation construct and other variables, different authors have researched the antecedents or factors that influence market orientation in the HE context and also the effects it has on other variables. In relation to the antecedents, Flavián and Lozano (2006) observed that the level of market orientation adopted by the university teaching staff is positively influenced by the predisposition of the department (to which the teachers belong) to take account of the needs of society, by the prestige awarded by the department and cohesion between the departmental teachers. Küster and Avilés-Valenzuela (2010) concluded that the campus market orientation did not have a positive significant impact on teaching staff orientation, but did have such an influence on school market orientation. For its effect on other variables, researches had provided evidence of a positive influence of market orientation on HEI performance (Caruana et al. 1998; Hammond et al. 2006; Zebal and Goodwin 2012) and departments (Ma and Todorovic 2011). A market-oriented behaviour by teaching staff also translated into better outcomes in their teaching, research and university extension activities (Flavián and Lozano 2007). Additionally, authors who have studied market orientation from the student perspective (sometimes labelled as "perceived market orientation") have drawn the conclusion that it has close associations with customer-perceived service quality (Voon 2008; Bakar et al. 2014), customer satisfaction (Voon 2008; Casidy 2014; Tanrikulu and Gelibolu 2015; Tran et al. 2015), customer loyalty (Voon 2008; Casidy 2014), word-of-mouth (Casidy 2014) and perceived brand equity (Tanrikulu and Gelibolu 2015). Lastly, the study of market orientation has more recently been extended to other contexts such as the export of universities' educational services to international students (Nagy and Berács 2012; Asaad et al. 2013; Asaad et al. 2015), or internal marketing (Carlos and Rodrigues 2012).

In general, the empirical works mentioned have adopted as a foundation stone for conceptualizing the market orientation in its different dimensions the cultural approach of Narver and Slater (1990) and Slater and Narver (1994), or the behavioural approach of Kohli and Jaworski (1990), Jaworski and Kohli (1993) and Kohli et al. (1993). As a result, the main dimensions through which market orientation in the HE field has been operationalized have been customer (student) orientation, competitor orientation, the inter-functional coordination of marketing activities, intelligence generation and dissemination and responsiveness. In some works, the orientation to other stakeholders has also been considered, among which the employee category stands out. Nonetheless, despite the important 
contributions represented by the adaptations made, the recent literature reflects continued calls for more effort to be employed in matching the concept to the specific context of $\mathrm{HE}$ (Liao 2008; Bugandwa 2009; Rivera-Camino and Molero Ayala 2010; Ma and Todorovic 2011; Bugandwa 2013; Tanrikulu and Gelibolu 2015) in order to overcome internal resistance towards ways of doing things imported from the business field (Liao 2008). Bugandwa (2009) even warns of the dangers involved in the development of empirical studies with deficiencies in contextualization and calls for "further investigations on the market orientation concept, prior to its use in empirical research in higher education settings $(\mathrm{Bu}-$ gandwa 2009, p.322)". And the fact is that, in the business field, customer satisfaction seems a natural aspiration, consideration of competitors' strengths and weaknesses is fully integrated within the strategic planning process and the relation between market orientation and performance is frequently measured through its impact on profitability, sales or asset return. But in the HE sector it is a more complex matter to establish who constitutes the principal customer (Naude and Ivy 1999; Helgesen 2008; Wasmer and Bruner II 2009), to distinguish the borderline between competitors and collaborators when thinking about other HEIs (Liao 2008; Bugandwa 2009; Bugandwa 2013), and to determine what constitutes the most appropriate way of measuring performance (Liao 2008; Duque 2014). These are the key aspects that we feel require deeper exploration if we are to enable application of the marketing concept in HEIs.

\section{A. From customer orientation to stakeholder orientation}

As to whether the university has one or more customers and how to establish exactly who they are, we observe discrepancies, different perspectives and a debate that remains open (Sirvanci 2004; Eagle and Brennan 2007; Marzo et al. 2007). The most widespread perspective considers that the main customers are the students (for instance, Guolla 1999; Menon 2002; Marzo et al. 2005; Redding 2005; White 2007; Helgesen 2008; García-Sanchis et al. 2015; Tanrikulu and Gelibolu 2015). However, a debate is also open as to whether students should or should not be treated as customers (Rivera-Camino and Molero Ayala 2010; Woodall et al. 2014; Koris and Nokelainen 2015). Consideration of students as customers has been interpreted as a particular manifestation of the free market (Saunders 2014) and, therefore, within a commercialization scheme for HE that establishes supplier-customer relations. Education becomes a simple transaction, in which the maxim that "the customer is always right" would be the rule. So, many teachers are reluctant to countenance students as university customers (Winter and O'Donohue 2012) and a host of arguments have been put forward to explain how unsuitable the use of this term is in the HE context. The works by Eagle and Brennan (2007) and Saunders (2014) contain review of the main critiques. Reference is made to asymmetries of knowledge between customer and supplier, as students do not know how to approach with precision what they really need in their training process. Another of the aspects refers to access criteria, since it is not always possible to attend a centre and enrol. Students do not buy the qualification as such, nor can they be sure they will obtain a job. Students as customers can adopt a posture of expecting good grades regardless of any effort made. They can transfer responsibility for their learning to the university, declining their part in the arrangement. A more passive attitude could be encouraged, radically altering the nature of education, and they might expect the teach- 
ing staff to entertain them, rather than steering part of their training towards autonomous learning. In short, a student being a customer "degrades educational standards and damages educator/student relationships (Eagle and Brennan 2007, p.44)".

Meanwhile, our knowledge of the degree to which students see themselves as customers is scant (Saunders 2014). One of the recent studies in this regard (Koris and Nokelainen 2015) concludes that students expect to be treated as customers in some, but not in all, categories of the educational experience. Thus, they do not expect to be treated as customers in curriculum design, rigour, classroom behaviour and graduation, but do expect to be treated as such in student feedback, classroom studies and, partially, in communication with administrative staff, individual studies, course design and teaching methods. Then there is another perspective that holds that the students comprise part of the raw materials, the graduates are the product and the employers constitute the university's customer (Boatwright and Stamps 1988; Sirvanci 2004). In this spirit, Litten (1980, p.47) argues that the student "is client, part of the process itself, and a quasi-product at the end of the process", and Ressler and Abratt (2009, p.39) maintain that "the student is not only a consumer of the education, but a designer of the education product and in essence becomes a product of the university on graduation". This highlights the fact that a student is not strictly a customer in the traditional sense of the term, as someone who acquires a product or a service, which is why greater adaptation and contextualization of the reference framework for marketing application is demanded.

The principal argument employed for regarding students as customers is that they pay for their education. Some authors, however, emphasize that students are not alone in defraying the costs of their education, and other collectives such as the family (Cardoso et al. 2011) or the State (Saunders 2014) also contribute to paying for it (Redding 2005; Eagle and Brennan 2007). Under this argument they hold that, even if it were accepted that students can be treated as customers of the university, one might ask whether other groups might also fall within that category. So another debate kicks in here. Beyond the semantic question of the appropriateness of the term customer to refer to students, lies the operational issue as to who university customers are, accepting, as we have remarked, that students are considered to be a stakeholder of overriding interest. In the literature other collectives that could be regarded as customers or stakeholders for the university have been described (Kotler and Fox 1995; Naude and Ivy 1999; Marzo et al. 2007). One of the most detailed reviews in this regard establishes nine stakeholders or types of customers of the university (Marzo et al.2007) and in it a broad consensus is observed among academics in considering students, employers, teaching and research personnel and society as the main customers or stakeholders for the university. In addition to these, others also appear, such as the Public Administration, families, administrative and service personnel, donors and/or sponsors and others, amongst whom would figure alumni and potential students.

The university is influenced by the considerations and decisions of these stakeholders and must, therefore, consider them and establish a suitable system of relations with them, developing a stakeholder orientation (Llonch et al. 2016). Even more so bearing in mind that, as a recent investigation concludes, universities can secure competitive advantages and provide better results in terms of reputation if they apply an orientation that is both sensitive and proactive towards stakeholders (Alarcón-del-Amo et al. 2016). This is why we consider that the term "customer orientation" does not offer the best match for the characteristics of the HE sector and feel it would be more appropriate to talk of an orientation towards society and even towards stakeholders. 


\section{B. From competitor orientation to co-opetitor orientation}

Competitor orientation, another of the cornerstones of market orientation, is also a necessary dimension to conceptualise the market orientation in the HE sector since universities compete for pupils, teachers and funding (Rivera-Camino and Molero Ayala 2010). However, it cannot be overlooked that the relation with competitors in the HE field is not completely comparable to that which is observed in the business sector, because there is a special interest in progressing jointly with them as partners (Liao 2008; Bugandwa 2009; Llonch et al. 2016). The drive for collaboration between universities is reflected both in the definition of their functions and in some of the indicators that are frequently used to measure the quality of their activities, above all in the research facet. So, universities see all the rest of the HEIs as competitors, but also as important collaborators. That is why we believe that the relatively new concept of co-opetition (Brandenburger and Nalebuff 1996) which is increasingly used in the business sector is particularly suitable for the sector we are studying, reflecting as it does the duality we have referred to. For this reason, we consider that a transition from "competitor orientation" to "co-opetitor orientation" would better fit the reality within which HEIs perform their activities.

\section{Perceptions of stakeholders as a measure of performance in universities}

As we have already indicated, in the business field the relation between market orientation and performance has often been measured through the effect on profitability, sales or asset return. In the HE sector this question is a matter of greater complexity (Pavicic et al. 2009). Due to the social function that universities play it would be advisable for measurements to encompass a review of the degree to which they are effective and efficient in reaching their objectives, which do not necessarily have to coincide with those of other kinds of organizations such as companies. Universities do not only operate under the guidance of the market to satisfy consumer needs, but are also motivated by their mission and their values to meet social needs. Moreover, as stated above, they have a duty to a diverse set of stakeholders whose needs do not always coincide.

In accordance with the number of works that undertake a study of the influence of market orientation on student satisfaction (Voon 2008; Casidy 2014; Tanrikulu and Gelibolu 2015; Tran et al.2015), this seems to be the principal aspect that the authors have deemed relevant as a measure of performance. Customer-perceived service quality (Voon 2008; Bakar et al. 2014), customer loyalty (Voon 2008; Casidy 2014) and other minority aspects such as student retention or word-of-mouth have also received attention from researchers. The above aspects bear a relation with the student, a single university stakeholder. Further, most of them prove to be problematic when the relation with the university has not been direct, which means that the possibility of analysis from the perspective of the stakeholders with whom such a relation may be indirect suffers (part of the business fabric and of society, for instance).

However, taking into account that universities have responsibility for a diversity of stakeholders (whether their relation with them is direct or indirect), we need to design measures that permit an analysis that can incorporate each or any one of them. In a similar vein, Ma and Todorovic (2011) state that, as a consequence of the different roles that universities 
perform in society and the different activities developed by HEIs, university performance has a multifaceted nature. In their view, therefore, "there is a need to develop a scale that will specifically measure multifaceted university performance (p.5)". We understood and share the perspective outlined by Ma and Todorovic (2011) and, despite not constituting an objective measure, we believe that the best way of measuring it is through the perceptions (image or reputation) that the different stakeholders hold regarding the achievements of universities in their different facets (teaching, research and dissemination of knowledge and culture). Such a measure is among those previously suggested by other authors (Kotler and Fox 1995; Pavicic et al. 2009; Duque 2014; Tran et al. 2015). In addition, this is a strategic aspect that universities have started to attribute greater importance and devote more resources to (Parameswaran and Glowacka 1995; Curtis et al. 2009; Maringe and Mourad 2012) as a result of the influence it has on HE choice (Hemsley-Brown and Oplatka 2016). But, also, consideration of perceptions as a measure of performance would enable the development of measurement instruments suitable for application upon different collectives, thereby facilitating the carrying out of comparative analyses among groups or stakeholders. So we consider that perceptions, understood as the image or reputation of universities, constitute an aspect of special relevance for measuring HEI performance.

\subsection{Extensions of the classical marketing orientation: particular suitability for the higher education context}

The considerations made in the previous section regarding operationalization of the marketing concept in the field of $\mathrm{HE}$ are consistent with the evolution experienced by marketing as a philosophy and fit in with two of the most prominent extensions that have been expounded in relation with the marketing orientation: societal marketing and holistic marketing.

The "societal marketing orientation" (Kotler 1972) constitutes an extension of the classical marketing orientation. It recognizes the importance of satisfying the needs of consumers while preserving their long-term welfare, and doing so without this occurring at the expense of the welfare of society. Clearly, this approach defends the need to balance three considerations when establishing marketing policies: company benefits, satisfaction of consumer desires and society's interests.

More recently, Keller and Kotler (2006) consider socially responsible behaviour as one of the aspects that characterize a broader approach: the "holistic marketing orientation" (Kotler et al. 2002). This focus underlines the importance of developing, designing and applying marketing programmes, processes and activities recognizing their reach and the interdependence that exists between their effects, as well as the need for them to be consistent with the decisions taken in other areas. From this perspective, there must be an awareness that "everything matters with marketing (Keller and Kotler 2006, p.300)": the consumer, the employees, other companies, competitors and society as a whole. Thus, application of the holistic marketing orientation is founded upon the joint consideration of the following four elements: performance marketing, related with the need to consider a diversity of measures in the assessment of marketing efforts (included amongst which is the social question); relationship marketing, directed at establishing firm lasting relations with the organization's stakeholders; internal marketing, with the underlying idea that all the members of the organization should adopt suitable marketing principles (especially 
members of Management); and integrated marketing, which emphasizes the need to coordinate the multiple marketing activities developed in it and synthesized in the marketing mix concept. The latter, integrated marketing, was in fact highlighted by a panel of twenty specialists from the field of HE marketing as the main challenge to be faced in that area because they considered that the "projection of a unified relevant brand image requires all areas of the university to work together (Hayes 2007, p.930)".

Therefore, despite the reticence encountered in the university sector, marketing philosophy (understood from the widespread perspective of holistic marketing) does not prejudice the demands that the different stakeholders and society as a whole place on universities. Quite the opposite is the case, since this management focus ought to promote improved knowledge and satisfaction of the needs of these collectives within the university institutions and, consequently, lead to greater effectiveness and efficiency in the shaping and implementation of actions aimed at them and to a better and distinctive image or reputation that bolsters their market position.

\section{MARKETING MANAGEMENT IN UNIVERSITY INSTITUTIONS: PROPOS- AL OF A FRAMEWORK}

With the aim of facilitating implementation of the holistic marketing philosophy in universities, in this work we outline a marketing management schema that takes into account both their particularities and those of their functions. This schema seeks to assist university institutions in working on the development of a favourable image, which would be achieved, however, through stakeholder satisfaction. The approach is, therefore, geared towards finding a balance in meeting the objectives of the university, the stakeholders and society in general.

The approach to marketing management has been made considering the nature of the main "products" offered by universities (teaching and research). But, additionally, heed was paid to the influence exerted by everything related with the corporate level (with the university itself) upon the university image. This aspect is especially important in the case that concerns us, because it also serves as an umbrella for the image of the units that provide their services (their Colleges, degrees, teachers, researchers) and the image of their graduates. For this reason, when drawing up the university marketing management schema, two models were integrated: the seven variable model proposed by Booms and Bitner (1981) in the sphere of services marketing, and the ten variable design proposed by Balmer (1998) in his seminal work on corporate marketing. The combination of both schemas is expected to furnish university institutions with greater clarity as to the variables on which it is recommendable to focus attention to be able to respond to the demands of their stakeholders and make progress towards the development of a favourable image.

The fundaments of services marketing (Lovelock 1983) have been considered because universities are multiservice organizations (García Sanchis 2012). Teaching and research constitute the core of service provision, but they are complemented by another set of services, from those supporting teaching and training (which includes libraries, study rooms, academic, professional or job counselling, etc.) to recreational and extra-academic services (cultural activities, accommodation, restaurant service, parking areas, modes of transport, 
etc.). And all of them, both the main and complementary services, make up the value proposition of universities.

In consequence, much of what has been researched in the commercial management area of services organizations is transferable to the HE context. This means that universities must pay attention to the particularities that produce in management characteristics such as the intangibility, heterogeneity, inseparability of production and consumption and perishability that are common to services (Zeithaml et al. 1985) and take into account the different manifestations that surround service provision (Grönroos 1990). That is to say, when managing the latter from a marketing orientation, it is desirable to control three variables in addition to the four proposals in the 4P model (Product, Price, Place and Promotion) from McCarthy "marketing mix" (1960). These are: the "People" who intervene in service provision, the "Physical evidence" of the place where the service is provided and the "Processes" through which the service is provided (Booms and Bitner 1981). Although there are exceptions such as Wasmer et al. (1997), who aligned themselves with the 4Cs model (Concept, Cost, Channel, Communication) proposed by Bruner II (1989), the 7Ps of services marketing provide the foundations of most marketing mix models proposed in the preceding literature for the case of HEIs (Kotler and Fox 1995; Maringe 2005; Ivy 2008; Newman and Jahdi 2009; Filip 2012; Gajic 2012; Ratiu and Avram 2013). Some of the proposals, however, incorporate certain adaptations compared with the original model: Newman and Jahdi (2009) renamed all the elements in order to project a more customer-oriented 7C model; Kotler and Fox (1995) and Filip (2012) concentrated their attention on Programmes instead of on Product; and Ivy (2008) put forward the following 7P model specifically designed for MBA recruitment: Programme, People, Price, Promotion, Prospectus (a split of the traditional Promotion element), Prominence (related to reputation), and Premiums (referring to aspects that add value to the offer, such as availability of on-campus accommodation or the possibilities of international mobility). In our opinion, limiting the conception of product to training programmes runs the risk of losing track of services complementary to educational provision and, above all, of some of the demands of stakeholders other than students. This is why, in our framework (see Figure 1), the traditional Product element has been kept. The prominent role acquired by perceptions in the model designed by Ivy (2008) (through the Prominence element) coincides with the importance of image and reputation that has been defended in this article. However, we feel that integration of the original services marketing 7Ps with the proposal from corporate marketing better acknowledges that leading role.

With reference to corporate marketing, a viewpoint proposed by Balmer in 1998 and revised by the same author in later works (in Balmer 2011 several of the approaches in this evolution can be consulted), its consideration for the design of the framework put forward here is due to the fact that it places the emphasis on the need to confer priority strategic importance to everything connected with the organization's corporate level. Indeed, corporate marketing argues that a powerful corporate brand is a source of differentiation for an entity (which in our opinion is particularly true in the university context), and reaches the conclusion that the organization itself is the principal factor that configures the perceptions that the stakeholders have of it (Curtis et al. 2009). So, grounded on a marketing philosophy and a consumer and stakeholder orientation, it bestows a leading role on the management of corporate identity and, in his seminal work, Balmer (1998) proposes an extension of 
the 4 Ps in McCarthy (1960), incorporating six additional Ps: the "Philosophy" of the organization; its "Personality" or the set of ideologies present in the organization; its staff or "People"; the way in which the "Performance" of the organization is assessed by its stakeholders in relation with its philosophy and competitors; issues associated with corporate image, corporate reputation and country of origin, which are referred to as "Perception"; and "Positioning" or representation in the stakeholders' mindset vis-à-vis its competitors.

In consequence, although there are some differences in the denomination and the meaning attributed to some of the variables, integrating Booms and Bitner (1981) within the initial proposal by Balmer (1998), we propose a schema of 13 variables for university marketing management (Figure 1). Highlighted in it are the aspects universities should focus their attention on in the management field following a marketing orientation, allocating a leading role to features linked with the corporate sphere.

Figure 1

\section{The 13 Ps of university marketing management}

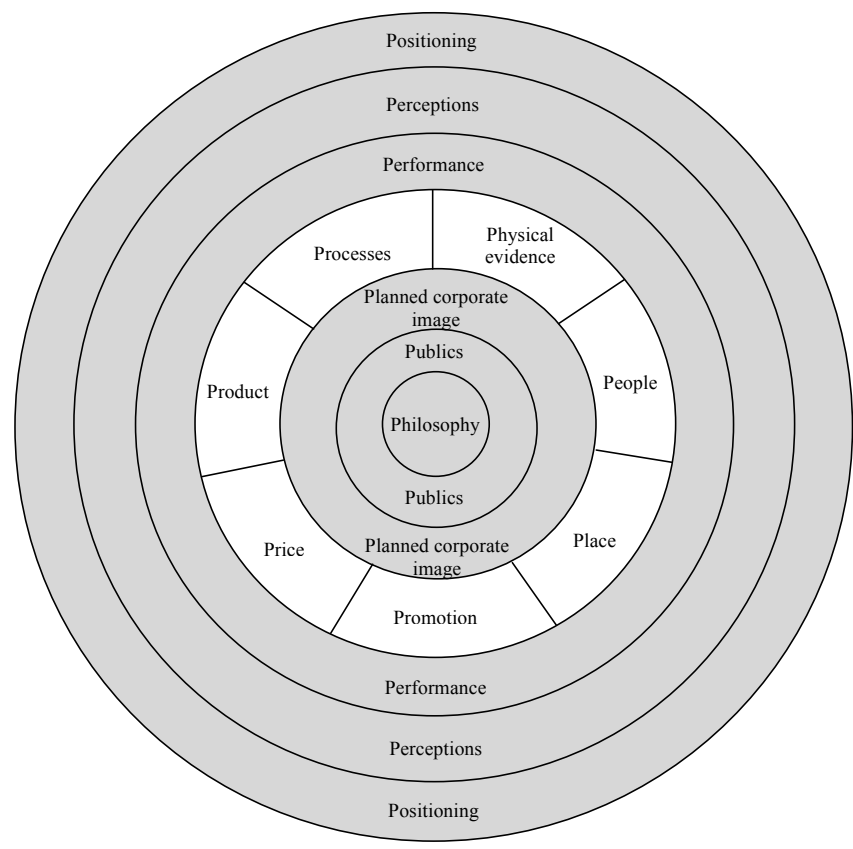

Source: Adapted from Balmer (1998)

The central core is university management under a philosophy of holistic marketing, where the need to target different publics or stakeholders is stressed. A deep knowledge of them would make it possible to identify what their needs are and the aspects that most contribute to the formation of the perceptions they hold of a university. That knowledge will place the institution in a more favourable position for determining the substantial features that must constitute its corporate identity and its planned corporate image or rep- 
utation. The latter should act as a guide for the definition of marketing strategies and actions associated both with its services and individual brands, and with the corporate level. This approach, therefore, suggests that universities should design their actions in order to achieve the set of features that, based on a deep knowledge of the stakeholders and of the organization itself, they have decided ought to characterize them. This behaviour is expected to contribute to improving the performance or achievements of the organization, aligning it with social demands, as well as to helping make the perceptions (image or reputation) that its stakeholders have of it, its services and its brands, more positive. Thereby the attainment of better market positioning should become possible, due to the possession of a competitive advantage.

\section{CONCLUSION}

The transformations experienced in the environment in which universities unfold their activities have increased the degree of competition in the sector and have introduced market elements. Many of these institutions have responded by placing emphasis on improving their training programmes, but this behaviour has not always translated into the creation of a more favourable image or reputation among their stakeholders. The key is that it is necessary to have a deeper knowledge of the needs of students and other stakeholders in the university.

Students, employers, teaching and research personnel and society are the stakeholders that are shown in the literature to be the most relevant for the university. Without neglecting relations with others, universities must pay these four groups special attention, trying to identify their needs, adapt to their demands and develop a proper system of relations. The twofold objective is to contribute to their satisfaction, and to the formation of favourable perceptions of the university that gives them service or represents them. After all, image and reputation, and not necessarily reality, is what people respond to.

This is why we feel that universities must consider deeper changes than the reform of degree courses and improvement of the programmes provided in their classrooms. What is necessary is a rethinking of the university management approach, moving from a product orientation, which is very widespread in universities, to a holistic marketing focus with a clear stakeholder orientation.

The application of marketing principles and/or practices in the university management field is met with much reluctance both among citizens and the academics themselves. This is, however, due to a misunderstanding of the discipline. Therefore, following the exposition of the reasons that may have given rise to this resistance, and rooted in the main adaptations suggested in this work for market orientation in the HE sector (the transition from a customer orientation to a stakeholder orientation, the move from a competitor orientation to a co-opetition orientation and the consideration of perceptions as a key element in the universities' performance measure), a marketing management schema is proposed aimed at assisting university managers to fluently implement marketing philosophy in university institutions. This framework has been built considering the relevance of stakeholder perceptions for universities and integrating the services marketing and corporate marketing proposals. In the belief that universities must design their actions seeking a balance be- 
tween achieving their own interests, those of their stakeholders and those of society, the framework proposed is expected to help universities create value for their different publics or stakeholders, while constructing a favourable image or reputation: these aspects do not always go hand in hand.

\section{ACKNOWLEDGEMENTS}

We thank the University of the Basque Country UPV/EHU for the financing received for developing Project NUPV 13/14, within which the development of this article is framed. We also thank the two anonymous reviewers whose comments and suggestions contributed a great deal to improving it.

\section{REFERENCES}

Alarcón-del-Amo, M.C., Casablancas-Segura, C. and Llonch, J., 2016. Responsive and proactive stakeholder orientation in public universities: Antecedents and consequences. Higher education, 72 (2), 131-151.

Alnawas, I., 2015. Student orientation in higher education: Development of the construct. Higher education, 69 (4), 625-652.

American Marketing Association, 2013. Definition of Marketing. Retrieved from: https:// www.ama.org/AboutAMA/Pages/Definition-of-Marketing.aspx [4 September 2015].

Asaad, Y., Melewar, T.C., Cohen, G. and Balmer, J.M.T., 2013. Universities and export market orientation: An exploratory study of UK post-92 universities. Marketing intelligence and planning, 31 (7), 838-856.

Asaad, Y., Melewar, T.C. and Cohen, G., 2015. Export market orientation behavior of universities: The British scenario. Journal of marketing for higher education, 25 (1), 127154.

Bakar, A.R.A., Talib, A.N.A. and Hashim, F., 2014. Restoring service quality, satisfaction and loyalty in higher education institutions through market orientation. Journal for global business advancement, 7 (1), 88-107.

Balmer, J.M.T., 1998. Corporate identity and the advent of corporate marketing. Journal of marketing management, 14 (8), 963-996.

Balmer, J.M.T., 2011. Corporate marketing myopia and the inexorable rise of a corporate marketing logic: Perspectives from identity-based views of the firm. European journal of marketing, 45 (9), 1329-1352.

Bardo, J.W., Ross, R.H. and Headley, E.L., 1990. Measuring alumni's image of a university. Journal for higher education management, 6 (1), 29-44.

Boatwright, E.W. and Stamps, M.B., 1988. Employers' importance ratings of student characteristics: A conjoint analysis approach. Journal of marketing education, 10 (2), 74-78.

Booms, B.H. and Bitner, M.J., 1981. Marketing strategies and organization structures for service firms. In: Donnelly, J.H. and George, W.R., eds. Marketing of services. Chicago: American Marketing Association, 47-51. 
Brandenburger, A. and Nalebuff, B., 1996. Co-opetition. New York: Doubleday.

Bruner II, G.C., 1989. The marketing mix: Time for reconceptualization. Journal of marketing education, 11 (2), 72-77.

Bugandwa, M.A.D., 2009. Is market orientation a relevant strategy for higher education institutions? International journal of quality and service sciences, 1 (3), 311-333.

Bugandwa, M.A.D., 2013. Beyond market orientation: An operationalisation of stakeholder orientation in higher education. African journal of marketing, 5 (3), 68-81.

Cardoso, S., Carvalho, T. and Santiago, R., 2011. From students to consumers: Reflections on the marketisation of Portuguese higher education. European journal of education, 46 (2), 271-284.

Carlos, V.S. and Rodrigues, R.G., 2012. Internal market orientation in higher education institutions - Its inter-relations with other organisational variables. Public policy and administration, 11 (4), 690-702.

Caruana, A., Ramaseshan, B. and Ewing, M.T., 1998. The market orientation-performance link: Some evidence from the public sector and universities. Journal of nonprofit and public sector marketing, 6 (1), 63-82.

Casidy, R., 2014. The role of perceived market orientation in the higher education sector. Australasian marketing journal, 22 (2), 155-163.

Çetin, R., 2004. Planning and implementing institutional image and promoting academic programs in higher education. Journal of marketing for higher education, 13 (1/2), $57-75$.

Conway, T., Mackay, S. and Yorke, D., 1994. Strategic planning in higher education: Who are the customers? The international journal of educational management, 8 (6), 29-36.

Curtis, T., Abratt, R. and Minor, W., 2009. Corporate brand management in higher education: The case of ERAU. Journal of product and brand management, 18 (6), 404-413.

Duque, L.C., 2014. A framework for analysing higher education performance: Students' satisfaction, perceived learning outcomes, and dropout intentions. Total quality management \& business excellence, 25 (1-2), 1-21.

Eagle, L. and Brennan, R., 2007. Are students customers? TQM and marketing perspectives. Quality assurance in education, 15 (1), 44-60.

Filip, A., 2012. Marketing theory applicability in higher education. Procedia - social and behavioral sciences, 46 912-916.

Flavián, C. and Lozano, J., 2004. La orientación al mercado de la Universidad pública: Un reto para el sistema universitario español. Revista internacional de marketing público y no lucrativo, 1 (2), 9-28.

Flavián, C. and Lozano, J., 2006. Organisational antecedents of market orientation in the public university system. International journal of public sector management, 19 (5), 447-467.

Flavián, C. and Lozano, J., 2007. Market orientation of Spanish public universities: A suitable response to the growing competition. Journal of marketing for higher education, 17 (1), 91-116.

Gajic, J., 2012. Importance of marketing mix in higher education institutions. Singidunum journal of applied sciences, 9 (1), 29-41. 
García Sanchis, M., 2012. Evaluación del servicio universitario. Una aproximación integradora a partir de la calidad, el valor y la satisfacción, desde un enfoque cross-cultural. Thesis, (Dr). Universitat de València.

García-Sanchis, M., Gil-Saura, I. and Berenguer-Contrí, G., 2015. Dimensionalidad del servicio universitario: Una aproximación desde un enfoque de marketing. Revista iberoamericana de educación superior, 6 (15), 26-49.

Gattermann, M., Hoffmann, C., Simoes, C. and Pólvora, R., 2012. Modeling antecedents of student loyalty in higher education. Journal of marketing for higher education, 22 (1), 101-116.

Grönroos, C., 1990. Service management and marketing: Managing the moments of truth in service competition. Lexington, MA: Lexington Books.

Guolla, M., 1999. Assessing the teaching quality to student satisfaction relationship: Applied customer satisfaction research in the classroom. Journal of marketing theory and practice, 7 (3), 87-97.

Hammond, K.L., Webster, R.L. and Harmon, H.A., 2006. Market orientation, top management emphasis, and performance within university schools of business: Implications for universities. Journal of marketing theory and practice, 14 (1), 69-85.

Hayes, T., 2007. Delphi study of the future of marketing of higher education. Journal of business research, 60 (9), 927-931.

Helgesen, Ø., 2008. Marketing for higher education: A relationship marketing approach. Journal of marketing for higher education, 18 (1), 50-78.

Hemsley-Brown, J. and Oplatka, I., 2006. Universities in a competitive global marketplace. The international journal of public sector management, 19 (4), 316-338.

Hemsley-Brown, J. and Oplatka, I., 2010. Market orientation in universities: A comparative study of two national higher education systems. International journal of educational management, 24 (3), 204-220.

Hemsley-Brown, J. and Oplatka, I., 2016. Higher education consumer choice. London: Palgrave Macmillan UK.

Ivy, J., 2008. A new higher education marketing mix: The 7Ps for MBA marketing. International journal of educational management, 22 (4), 288-299.

Jaworski, B.J. and Kohli, A.K., 1993. Market orientation: Antecedents and consequences. Journal of marketing, 57 (3), 53-70.

Kalenskaya, N., Gafurov, I. and Novenkova, A., 2013. Marketing of educational services: Research on service providers satisfaction. Procedia economics and finance, 5, 368376.

Keller, G., 1983. Academic strategy: The management revolution in American higher education. Baltimore: The Johns Hopkins University Press.

Keller, K.L. and Kotler, P., 2006. Holistic marketing: A broad, integrated perspectice to marketing management. In: Sheth, J.N. and Sisodia, R.S., eds. Does marketing need reform? Fresh perspectives on the future. New York: M.E. Sharpe, 300-305.

Kohli, A.K. and Jaworski, B.J., 1990. Market orientation: The construct, research propositions, and managerial implications. Journal of marketing, 54 (2), 1-18.

Kohli, A.K., Jaworski, B.J. and Kumar, A., 1993. MARKOR: A measure of market orientation. Journal of marketing research, 30 (4), 467-477. 
Koris, R. and Nokelainen, P., 2015. The student-customer orientation questionnaire (SCOQ): Application of customer metaphor to higher education. International journal of educational management, 29 (1), 115-138.

Kotler, P., 1972. What consumerism means for marketers. Harvard business review, 50 (3), 48-57.

Kotler, P. and Fox, K., 1995. Strategic marketing for educational institutions. 2nd ed. Upper Saddle River, NJ: Prentice Hall.

Kotler, P., Jain, D.C. and Maesincee, S., 2002. Marketing moves: A new approach to profits, growth, and renewal. Boston: Harvard Business School Press.

Küster, I. and Avilés-Valenzuela, M.E., 2010. Market orientation in university: A case study. International journal of educational management, 24 (7), 597-614.

Liao, M.N., 2008. Applying the marketing concept in higher education. In: Sargeant, A. and Wymer, W., eds. The Routledge companion to nonprofit marketing. Abingdon: Routledge, 270-282.

Litten, L.H., 1980. Marketing higher education: Benefits and risks for the American Academic System. The journal of higher education, 51 (1), 40-59.

Liu, S.S., 1998. Integrating strategic marketing on an institutional level. Journal of marketing for higher education, 8 (4), 17-28.

Llonch, J., Casablancas-Segura, C. and Alarcón-del-Amo, M.C., 2016. Stakeholder orientation in public universities: A conceptual discussion and a scale development. Spanish journal of marketing - esic, 20 (01), 41-57.

Lovelock, C.H., 1983. Classifying services to gain strategic marketing insights. Journal of marketing, 47 (3), 9-20.

Ma, J. and Todorovic, Z., 2011. Making universities relevant: Market orientation as a dynamic capability within institutions of higher learning. Academy of marketing studies journal, $15,1$.

Mägi, E., Jaakson, K., Aidla, A., Kirss, L. and Reino, A., 2012. Full-time employed students as university consumers - consequences and triggers of marketisation of higher education. European journal of higher education, 2 (2-3), 248-266.

Mainardes, E.W., Raposo, M. and Alves, H., 2014. Universities need a market orientation to attract non-traditional stakeholders as new financing sources. Public organization review, 14 (2), 159-171.

Maringe, F., 2004. Vice chancellors' perceptions of university marketing: A view from universities in a developing country. Higher education review, 36 (2), 53-68.

Maringe, F., 2005. Interrogating the crisis in higher education marketing: The CORD model. International journal of educational management, 19 (7), 564-578.

Maringe, F. and Gibbs, P., 2009. Marketing higher education: Theory and practice. UK: McGraw-Hill.

Maringe, F. and Mourad, M., 2012. Marketing for higher education in developing countries: Emphasis and omissions. Journal of marketing for higher education, 22 (1), 1-9.

Marzo, M., Pedraja, M. and Rivera, P., 2005. A new management element for universities: Satisfaction with the offered courses. International journal of educational management, 19 (6), 505-526.

Marzo, M., Pedraja, M. and Rivera, P., 2007. The customer concept in university services: A classification. International review on public and nonprofit marketing , 4 (1/2), 65-80. 
Mavondo, F.T., Tsarenko, Y. and Gabbott, M., 2008. International and local student satisfaction: Resources and capabilities perspective. Journal of marketing for higher education, 14 (1), 41-60.

McCarthy, E.J., 1960. Basic marketing: A managerial approach. Homewood, IL: Irwin.

Menon, M.E., 2002. The mission of universities and the vocational paradigm: An investigation of students' perceptions. Journal of vocational education and training, 54 (4), 515-532.

Nagy, G. and Berács, J., 2012. Antecedents to the export market orientation of Hungarian higher education institutions, and their export performance consequences. Journal of marketing for higher education, 22 (2), 231-256.

Narver, J.C. and Slater, S.F., 1990. The effect of a market orientation on business profitability. Journal of marketing, 54 (4), 16-20.

Natale, S.M. and Doran, C., 2012. Marketization of education: An ethical dilemma. Journal of business ethics, 105 (2), 187-196.

Naude, P. and Ivy, J., 1999. The marketing strategies of universities in the United Kingdom. The international journal of educational management, 13 (3), 126-134.

Nedbalová, E., Greenacre, L. and Schulz, J., 2014. UK higher education viewed through the marketization and marketing lenses. Journal of marketing for higher education, 24 (2), 178-195.

Newman, C.M., 2002. The current state of marketing activity among higher education institutions. Journal of marketing for higher education, 12 (1), 15-29.

Newman, S. and Jahdi, K., 2009. Marketisation of education: Marketing, rhetoric and reality. Journal of further and higher education, 33 (1), 1-11.

Parameswaran, R. and Glowacka, A.E., 1995. University image: An information processing perspective. Journal of marketing for higher education, 6 (2), 41-56.

Pavicic, J., Alfirevic, N. and Mihanovic, Z., 2009. Market orientation in managing relationships with multiple constituencies of Croatian higher education. Higher education, 57 (2), 191-207.

Ratiu, M.P. and Avram, E.M., 2013. Optimizing the marketing Mix - An essential element in developing competitive strategies in the field of higher education. Romanian economic and business review, 8 (1), 57.

Redding, P., 2005. The evolving interpretations of customers in higher education: Empowering the elusive. International journal of consumer studies, 29 (5), 409-417.

Ressler, J. and Abratt, R., 2009. Assessing the impact of university reputation on stakeholder intentions. Journal of general management, 35 (1), 35-45.

Rivera-Camino, J. and Molero Ayala, V., 2010. Market orientation at universities: Construct and exploratory validation. Innovar, 20 (36), 125-138.

Saunders, D.B., 2014. Exploring a customer orientation: Free-market logic and college students. The review of higher education, 37 (2), 197-219.

Sirvanci, M.B., 2004. Critical issues for TQM implementation in higher education. The tqm magazine, 16 (6), 382-386.

Siu, N.Y.M. and Wilson, R.M.S., 1998. Modelling market orientation: An application in the education sector. Journal of marketing management, 14 (293), 323.

Slater, S.F. and Narver, J.C., 1994. Does competitive environment moderate the market orientation-performance relationship? Journal of marketing, 58 (1), 46-55. 
Soutar, G.N. and Turner, J.P., 2002. Students' preferences for university: A conjoint analysis. International journal of educational management, 16 (1), 40-45.

Stewart, K.L., 1991. Applying a marketing orientation to a higher education setting. Journal of professional services marketing, 7 (2), 117-124.

Stimac, H. and Simic, M.L., 2012. Competitiveness in higher education: A need for marketing orientation and service quality. Economics and sociology, 5 (2), 23-34.

Tanrikulu, C. and Gelibolu, L., 2015. The impacts of perceived market orientation in higher education: Student as a customer. Revista de cercetare si interventie sociala, 49, 156-172.

Tran, T.P., Blankson, C. and Roswinanto, W., 2015. Market orientation: An option for universities to adopt? International journal of nonprofit and voluntary sector marketing, 20 (4), 347-365.

Voon, B.H., 2008. SERVMO: A measure for service-driven market orientation in higher education. Journal of marketing for higher education, 17 (2), 216-237.

Wasmer, D.J., Williams, J.R. and Stevenson, J., 1997. A reconceptualization of the marketing mix: Using the $4 \mathrm{C}$ 's to improve marketing planning in higher education. Journal of marketing for higher education, 8 (2), 29-35.

Wasmer, D.J. and Bruner II, G.C., 2009. The antecedents of the market orientation in higher education. Journal of marketing for higher education, 9 (2), 93-105.

White, N.R., 2007. The customer is always right?: Student discourse about higher education in Australia. Higher education, 54 (4), 593-604.

Winter, R.P. and O'Donohue, W., 2012. Academic identity tensions in the public university: Which values really matter? Journal of higher education policy and management, 34 (6), 565-573.

Woodall, T., Hiller, A. and Resnick, S., 2014. Making sense of higher education: Students as consumers and the value of the university experience. Studies in higher education, 39 (1), 48-67.

Yavas, U. and Shemwell, D.J., 1996. Graphical representation of university image: A correspondence analysis. Journal of marketing for higher education, 7 (2), 75-84.

Zebal, M.A. and Goodwin, D.R., 2012. Market orientation and performance in private universities. Marketing intelligence and planning, 30 (3), 339-357.

Zeithaml, V.A., Parasuraman, A. and Berry, L.L., 1985. Problems and strategies in services marketing. Journal of marketing, 49 (2), 33-46. 
